\title{
Halomonas cerina sp. nov., a moderately halophilic, denitrifying, exopolysaccharide-producing bacterium
}

\author{
Carmen M. González-Domenech, Fernando Martínez-Checa, \\ Emilia Quesada and Victoria Béjar
}

Correspondence

Victoria Béjar

vbejar@ugr.es

\author{
Microbial Exopolysaccharide Research Group, Department of Microbiology, Faculty of Pharmacy, \\ Campus Universitario de Cartuja, University of Granada, 18071 Granada, Spain
}

\begin{abstract}
Three bacterial strains were isolated from different saline soils in Spain. The novel strains were moderately halophilic, exopolysaccharide-producing, Gram-negative, non-motile rods. The strains required $\mathrm{NaCl}$ and grew best with $7.5-10 \%(\mathrm{w} / \mathrm{v}) \mathrm{NaCl}$ in the medium. They formed waxcoloured colonies, were oxidase-positive and showed respiratory metabolism, using oxygen, nitrate and nitrite as terminal electron acceptors. The novel strains were able to denitrify and did not produce acid from sugars. The DNA G+C contents varied between 62.7 and $66.2 \mathrm{~mol} \%$. Phylogenetic analyses based on 16S rRNA gene sequences and sequence signatures of this gene showed that all three novel isolates belonged to the genus Halomonas in the class Gammaproteobacteria and formed an independent phylogenetic line. The most phylogenetically related species were Halomonas alimentaria, Halomonas campaniensis, Halomonas gudaonensis and Halomonas ventosae, with which the novel strains showed 16S rRNA gene sequence similarity values of between 96.3 and $95.2 \%$. The principal fatty acids of the novel strains were $16: 0,18: 1 \omega 7 c, 16: 1 \omega 7 c$ and $19: 0$ cyclo $\omega 8 c$. The predominant respiratory lipoquinone was ubiquinone with nine isoprene units (Q-9). The name Halomonas cerina sp. nov. is proposed for these isolates. The type strain is SP4 $4^{\top}\left(=\right.$ CECT $7282^{\top}=$ LMG $\left.24145^{\top}\right)$.
\end{abstract}

The family Halomonadaceae belongs to the class Gammaproteobacteria and includes three genera of halophilic bacteria: Halomonas, Chromohalobacter and Cobetia, plus two genera of non-halophilic bacteria, Zymobacter and Carnimonas (Garrity et al., 2005). The genus Halomonas currently contains more than forty species (Euzéby, 2007). Its members are Gram-negative, rod-shaped, nonsporulating, aerobic, chemo-organotrophs with predominantly respiratory metabolisms, which use oxygen or, more rarely, nitrate as electron acceptors (Franzmann et al., 1988; Dobson \& Franzmann, 1996; Mata et al., 2002; Vreeland, 2005); a few species have a fermentative metabolism. Colonies range from white to yellow in colour. Most species of the genus Halomonas are found in hypersaline habitats and tend to be moderate halophiles, although some members of the genus could be classified as being halotolerant. Their DNA $\mathrm{G}+\mathrm{C}$ content ranges widely,

Abbreviations: EPS, exopolysaccharide; PHA, poly- $\beta$-hydroxyalkanoate. The GenBank/EMBL/DDBJ accession numbers for the 16S rRNA gene sequences of strains $15 \mathrm{CR}, \mathrm{SP} 4^{\top}$ and R53 are EF613111, EF613112 and EF613110, respectively.

A dendrogram of phenotypic characteristics based on the simplematching coefficient and UPGMA methods is available with the online version of this paper. between $54 \mathrm{~mol} \%$ for Halomonas halocynthiae (Romanenko et al., 2002) and $74.3 \mathrm{~mol} \%$ for Halomonas ventosae (Martínez-Cánovas et al., 2004b). Their principal fatty acids are: $16: 1$ cis $9,16: 0,17: 0$ cyclo, $18: 1$ and 19:0 cyclo 11-12 and the major isoprenoid quinone is ubiquinone 9 (Franzmann \& Tindall, 1990). The Halomonas species described by our group, Halomonas eurihalina (Quesada et al., 1990), Halomonas maura (Bouchotroch et al., 2001), Halomonas almeriensis (Martínez-Checa et al., 2005), Halomonas anticariensis (Martínez-Cánovas et al., 2004a) and $H$. ventosae (Martínez-Cánovas et al., 2004b), produce exopolysaccharides (EPSs) with potential applications in biotechnology (Arias et al., 2003; Quesada et al., 2004). Our research indicates that besides the species cited, other EPSproducing bacterial strains found in hypersaline habitats cannot be assigned to any currently recognized species of the genus Halomonas.

In this study, we classify three hitherto unassigned exopolysaccharide-producing Halomonas strains that are characterized by their capacity to denitrify. On the basis of their phenotypic features, comparative studies of their 16S rRNA gene sequences and DNA-DNA hybridization, followed by analyses of their fatty acid and isoprenoid quinone contents, they are proposed as representing a novel species of the genus Halomonas. 
The novel strains, $15 \mathrm{CR}, \mathrm{SP} 4^{\mathrm{T}}$ and $\mathrm{R} 53$, were isolated from hypersaline soils at Fuente de Piedra (Malaga), Santa Pola (Alicante) and Rambla Salada (Murcia), respectively, in the south of Spain. All of the strains were routinely grown in MY medium (Moraine \& Rogovin, 1966) with $7.5 \%(\mathrm{w} / \mathrm{v})$ sea salt solutions (Rodríguez-Valera et al., 1981) at $32{ }^{\circ} \mathrm{C}$. The strains included in Fig. 1 and Supplementary Fig. S1 (available in IJSEM Online) were used for phylogenetic and phenotypic comparisons, respectively.

The procedures followed for phenotypic characterization were as described in Ventosa et al. (1982), Quesada et al. (1983) and Mata et al. (2002). Anaerobic nitrate and nitrite reduction were tested according to Stanier et al. (1966). Characteristics common to all three strains are given in the species description. Phenotypic features that varied between the three strains are shown in Table 1. We compared the novel strains to other species of the genus Halomonas by a numerical analysis based on 107 phenotypic data. The data were submitted to cluster analysis using the simple matching coefficient $\left(\mathrm{S}_{\mathrm{SM}}\right)$ (Sokal \& Michener, 1958) and clustering was achieved by the unweighted pair group method of association (UPGMA) (Sneath \& Sokal, 1973). Computer analysis was performed with the TAXAN program (Information Resources Group). The dendrogram obtained is shown in Supplementary Fig. S1, where it can be seen that at $88 \%$ similarity, the three strains group into one phenon, which shared less than $78 \%$ similarity with any other species belonging to the genus Halomonas.

Table 2 shows the main phenotypic differences between the novel species and other related species of the genus Halomonas.
The DNA G $+\mathrm{C}$ content was estimated from the midpoint value $\left(T_{\mathrm{m}}\right)$ of the thermal denaturation profile (Marmur \& Doty, 1962) using the equation of Owen \& Hill (1979). The $\mathrm{G}+\mathrm{C}$ content of reference DNA from Escherichia coli NCTC $9001^{\mathrm{T}}$ was taken to be $50.8 \mathrm{~mol} \%$ (Owen \& Pitcher, 1985). The values obtained were $62.7 \mathrm{~mol} \%$, $66.2 \mathrm{~mol} \%$ and $66.3 \mathrm{~mol} \%$ for strains $15 \mathrm{CR}, \mathrm{R} 53$ and SP $4^{\mathrm{T}}$, respectively.

Phylogenetic analyses based on the 16S rRNA gene sequence were made as described in Bouchotroch et al. (2001). The sequences were compared to reference $16 \mathrm{~S}$ rRNA gene sequences available in the GenBank and EMBL databases obtained from the National Center of Biotechnology Information database using the BLAST search. Phylogenetic analyses were carried out using MEGA software version 3.1 (Kumar et al., 2004) after multiple alignments of data by CLUSTAL_X (Thompson et al., 1997). Distances and clustering with the neighbour-joining and maximum-parsimony methods were determined by using bootstrap values based on 1000 replications.

We determined almost the entire $16 \mathrm{~S}$ rRNA gene sequences of the three novel strains: $15 \mathrm{CR}(1436 \mathrm{bp}), \mathrm{SP} 4^{\mathrm{T}}(1449 \mathrm{bp})$ and R53 (1486 bp). The fragments analysed contained the 15 signature nucleotides defined for the family Halomonadaceae and the four defined for the genus Halomonas (Dobson \& Franzmann, 1996). The phylogenetic tree constructed using the neighbour-joining algorithm is shown in Fig. 1. The maximum-parsimony algorithm gave a similar result (data not shown). The three sequences shared more than $99.4 \%$ similarity and were on the same separate phylogenetic branch. The most

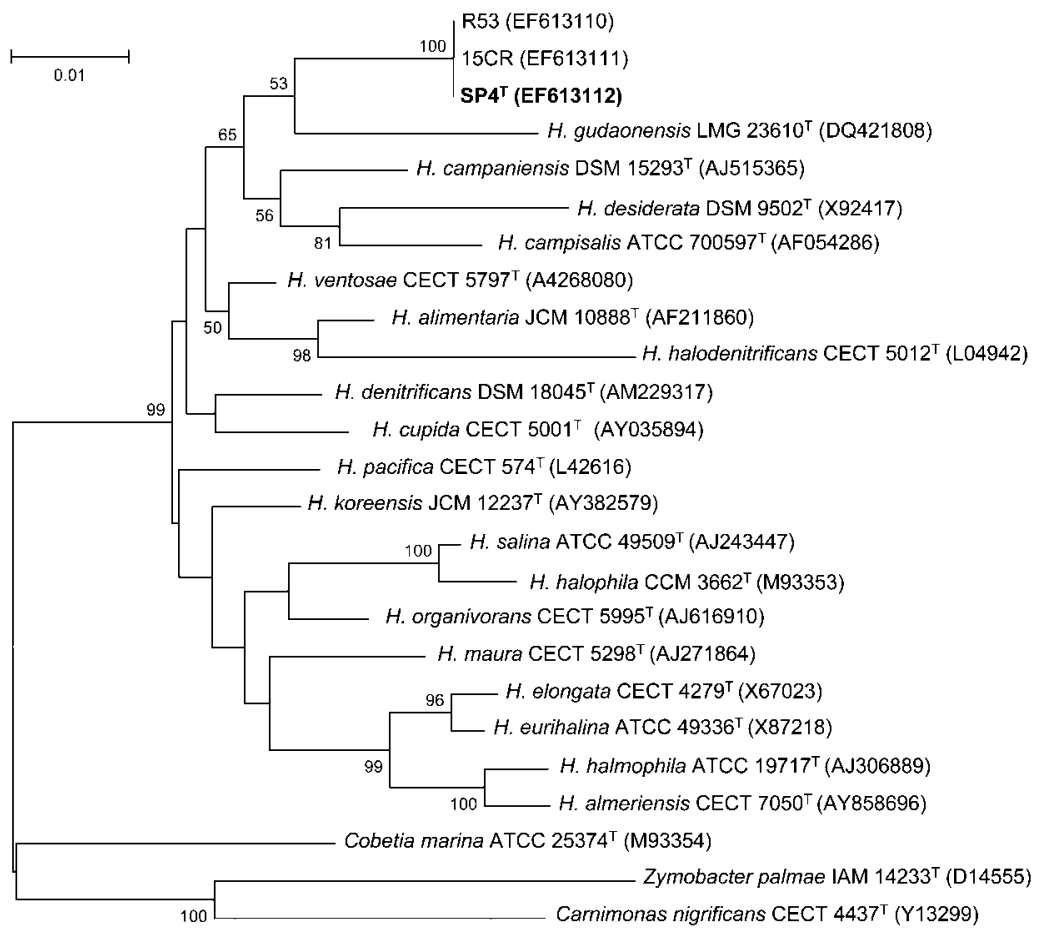

Fig. 1. Phylogenetic tree based on $16 \mathrm{~S}$ rRNA gene sequences, showing the position of the novel group of three isolates compared with other species of the genus Halomonas. The tree was obtained using the neighbour-joining algorithm. GenBank/EMBL/DDBJ accession numbers are given in parentheses. Numbers at nodes are bootstrap percentages from 1000 replications. Bar, $1 \%$ sequence divergence. 
Table 1. Characteristics that distinguish between strains $15 \mathrm{CR}, \mathrm{R} 53$ and SP4 ${ }^{\top}$

\begin{tabular}{|c|c|c|c|}
\hline Characteristic & 15CR & $S P 4^{T}$ & R53 \\
\hline Size $(\mu \mathrm{m})$ & $2.8 \times 0.7$ & $1.9 \times 0.7$ & $2.2 \times 0.9$ \\
\hline $\begin{array}{l}\text { Growth on } 5 \% \\
(w / v) ~ \\
\mathrm{NaCl}\end{array}$ & + & + & - \\
\hline $\begin{array}{l}\text { Resistance to } 80{ }^{\circ} \mathrm{C} \\
\text { for } 10 \mathrm{~min}\end{array}$ & - & - & + \\
\hline Tween 80 hydrolysis & + & + & - \\
\hline Gelatinase & - & - & + \\
\hline Tyrosine hydrolysis & + & + & - \\
\hline \multicolumn{4}{|l|}{ Growth on: } \\
\hline Adonitol & - & - & + \\
\hline Arabinose & - & - & + \\
\hline Cellobiose & + & - & - \\
\hline Ethanol & + & + & - \\
\hline Fructose & + & - & - \\
\hline Glycerol & + & - & - \\
\hline Histidine & + & - & - \\
\hline Inositol & + & - & - \\
\hline Lactate & + & - & + \\
\hline Lactose & - & - & + \\
\hline Mannitol & - & - & + \\
\hline Salicin & - & + & - \\
\hline Serine & + & + & - \\
\hline Starch & + & - & + \\
\hline Trehalose & + & - & - \\
\hline \multicolumn{4}{|c|}{ Principal fatty acids (\%):* } \\
\hline $10: 0$ & 2.30 & 2.60 & 2.35 \\
\hline $12: 0$ & 3.07 & 3.19 & 3.26 \\
\hline $12: 03-\mathrm{OH}$ & 5.43 & 6.22 & 5.98 \\
\hline $16: 1 \omega 7 c$ & 20.81 & 18.72 & 14.19 \\
\hline $16: 0$ & 30.91 & 33.93 & 24.01 \\
\hline $18: 1 \omega 7 c$ & 23.76 & 16.08 & 42.23 \\
\hline $18: 0$ & 3.06 & 1.55 & 3.79 \\
\hline 19: 0 cyclo $\omega 8 c$ & 9.40 & 14.46 & 4.18 \\
\hline \multirow[t]{2}{*}{ Lipoquinones } & Ubiquinone & \multicolumn{2}{|c|}{ Ubiquinone Ubiquinone $9,94 \%$} \\
\hline & 9 & 9 & Ubiquinone $8,6 \%$ \\
\hline $\begin{array}{l}\mathrm{DNA} G+\mathrm{C} \\
(\mathrm{mol} \%)\end{array}$ & 62.7 & 66.2 & 66.2 \\
\hline
\end{tabular}

${ }^{\star}$ Only fatty acids with a percentage higher than $2 \%$ are shown.

phylogenetically related species were Halomonas alimentaria, Halomonas campaniensis, Halomonas gudaonensis and $H$. ventosae, with which the novel strains showed $16 \mathrm{~S}$ rRNA gene sequence similarity values of between 96.3 and $95.2 \%$.

DNA-DNA hybridization was conducted following Lind \& Ursing's methods (Lind \& Ursing, 1986) with the modifications of Ziemke et al. (1998) and Bouchotroch et al. (2001). The comparative values for all three strains were higher than $80 \%\left(15 \mathrm{CR}\right.$ with $\mathrm{SP} 4^{\mathrm{T}}: 89.16 \%$; $15 \mathrm{CR}$ with R53: $80.50 \%$; R53 with SP4 ${ }^{\mathrm{T}}$ : $87.37 \%$; the reciprocal values were very similar). These data demonstrate that the three novel strains belong to the same species.
Transmission electron micrographs obtained using the methods of Bouchotroch et al. (2001) show the cell morphology of the three strains (Fig. 2). The cells contained poly- $\beta$-hydroxyalkanoate (PHA) granules.

Fatty acids and quinones were identified by high-resolution GLC and HPLC, respectively, by the Identification Service of the DSMZ, Braunschweig, Germany. The results are given in Table 1 and in the species description. The three strains showed a combination of fatty acids found in species of the genus Halomonas: predominantly 16:0, $18: 1 \omega 7,16: 1 \omega 7 c$ and 19:0 cyclo $\omega 8 c$ (Dobson \& Franzmann, 1996). An analysis of the quinones showed that all three strains contained ubiquinone 9; strain R53 also contained a small quantity $(6 \%)$ of ubiquinone 8 .

On the basis of the phylogenetic evidence, DNA-DNA hybridization values, fatty acid profiles, quinones and differences in phenotypic characteristics, we suggest that the denitrifying EPS-producing strains $15 \mathrm{CR}, \mathrm{SP} 4^{\mathrm{T}}$ and R53 represent a novel species of the genus Halomonas, for which the name Halomonas cerina sp. nov. is proposed.

\section{Description of Halomonas cerina sp. nov.}

Halomonas cerina (cer.i'na. L. fem. adj. cerina the colour of beeswax, describing the colour of the mature colonies).

Cells are straight, Gram-negative rods, 1.9-2.8 $\times 0.7-$ $0.9 \mu \mathrm{m}$, appearing either singly or in pairs. Cells are capsulated and non-motile. Cells accumulate PHA and do not form endospores. Cell colonies are wax coloured, circular, convex and mucoid. The growth pattern is uniform in a liquid medium. Moderate halophile, capable of growing in mixed-sea salt concentrations of 3-25\% $(\mathrm{w} / \mathrm{v})$, with optimum growth occurring between 7.5 and $10 \%$. Requires $\mathrm{NaCl}$ and can grow within a range of 7.5$20 \%(\mathrm{w} / \mathrm{v})$, the optimum being $7.5-10 \%$. Grows within a temperature range of $4-45{ }^{\circ} \mathrm{C}$ at $\mathrm{pH}$ values of between 5 and 10 , the optimum values being $20-32{ }^{\circ} \mathrm{C}$ and $\mathrm{pH} 7-8$. Catalase and oxidase are produced. Chemo-organotrophic. Metabolism is respiratory with oxygen, nitrate and nitrite as terminal electron acceptors. Respiration with fumarate is negative. Under aerobic conditions, selenite and nitrate are reduced. Acids are not produced from adonitol, Larabinose, D-fructose, D-galactose, D-glucose, glycerol, myo-inositol, lactose, maltose, D-mannitol, D-mannose, melezitose, L-rhamnose, D-salicin, D-sorbitol, sorbose, sucrose, trehalose or D-xylose. Indole, methyl red, VogesProskauer, O/F and ONPG tests give a negative result. Does not produce pyocyanin, fluorescein or pigment in tyrosine medium. Does not hydrolyse starch, casein, lecithin or aesculin. Produces urease, phosphatase and DNase but not phenylalanine deaminase. Gluconate is oxidized. Does not produce $\mathrm{H}_{2} \mathrm{~S}$ from L-cysteine. Grows on MacConkey agar but not on cetrimide agar. Blood is not lysed. The following compounds serve as sole carbon and energy sources: acetate, citrate, fumarate, D-gluconate, succinate, D-glucose, maltose and D-mannose, whilst aesculin, 
Table 2. Characteristics that distinguish Halomonas cerina $\mathrm{SP} 4^{\top}$ sp. nov. from other related species of the genus $H a l o m o n a s$

Taxa: 1 , H. cerina SP4 ${ }^{\mathrm{T}}$ sp. nov.; 2, H. alimentaria; 3, H. campaniensis; 4, H. campisalis; 5, H. desiderata; 6, H. gudaonensis; 7, H. ventosae. Data are from Ventosa et al. (1998), Mata et al. (2002), Yoon et al. (2002), Martínez-Cánovas et al. (2004b), Romano et al. (2005), Wang et al. (2007) and from this study. All species are Gram-negative rods, are catalase- and oxidase-positive, are able to reduce nitrate to nitrite and are able to grow with acetate, maltose or glucose as sole carbon and energy source. They do not hydrolyse starch or gelatin.

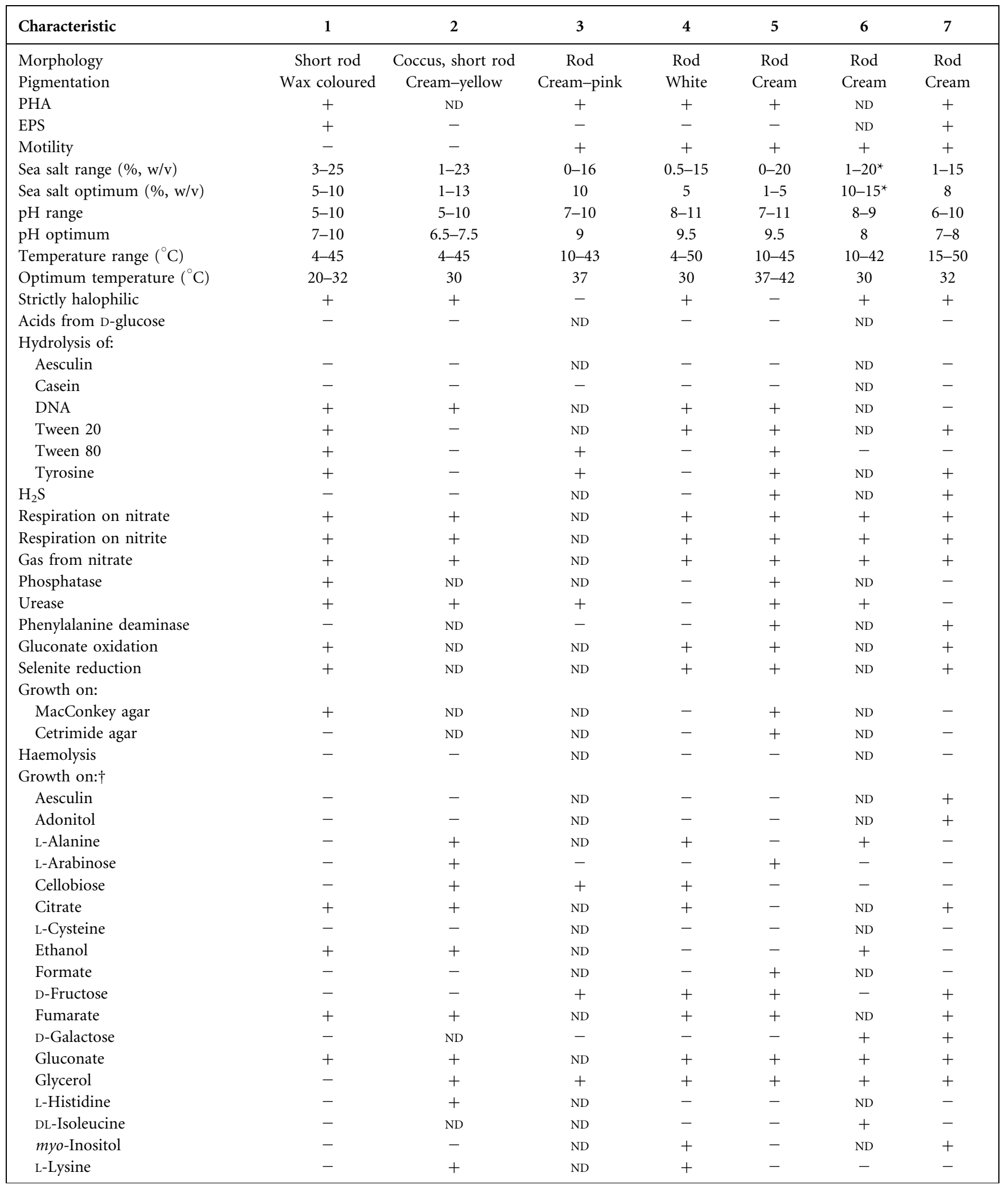


Table 2. cont.

\begin{tabular}{|c|c|c|c|c|c|c|c|}
\hline Characteristic & 1 & 2 & 3 & 4 & 5 & 6 & 7 \\
\hline D-Mannitol & - & + & ND & - & - & + & + \\
\hline Melezitose & - & $\mathrm{ND}$ & $\mathrm{ND}$ & - & + & $\mathrm{ND}$ & $\mathrm{ND}$ \\
\hline L-Methionine & - & $\mathrm{ND}$ & $\mathrm{ND}$ & - & - & ND & - \\
\hline Propionate & - & + & ND & + & - & ND & + \\
\hline Sorbitol & - & + & $\mathrm{ND}$ & - & - & $\mathrm{ND}$ & + \\
\hline Starch & - & + & $\mathrm{ND}$ & + & + & ND & - \\
\hline Succinate & + & - & $\mathrm{ND}$ & + & + & ND & + \\
\hline Trehalose & - & + & $\mathrm{ND}$ & + & + & + & + \\
\hline L-Valine & - & + & ND & - & - & $\mathrm{ND}$ & - \\
\hline
\end{tabular}

${ }^{\star} \mathrm{NaCl}$.

†When supplied as the sole source of carbon and energy or as sole source of carbon, nitrogen and energy.

galactose, formate, malonate and sorbitol do not. L-Alanine, L-isoleucine, L-cysteine, L-lysine, L-methionine and L-valine cannot be used as sole sources of carbon, nitrogen and energy. Susceptible to (amounts per disc): amoxicillin + clavulanic acid $(25 \mu \mathrm{g})$, ampicillin $(10 \mu \mathrm{g})$, aztreonam $(30 \mu \mathrm{g})$, cephalothin $(30 \mu \mathrm{g})$, cefoxitin $(30 \mu \mathrm{g})$, ceftazidine $(30 \mu \mathrm{g})$, doxycycline $(30 \mathrm{U})$, gentamicin $(10 \mu \mathrm{g})$, nalidixic acid $(30 \mu \mathrm{g})$, norfloxacin $(10 \mu \mathrm{g})$, nitrofurantoin $(300 \mu \mathrm{g})$, polymyxin $\mathrm{B}(300 \mathrm{U})$, rifampicin $(30 \mu \mathrm{g})$, sulphamide $(250 \mu \mathrm{g})$ and trimetroprim + sulphametoxazol $(1.25-23.75 \mu \mathrm{g})$. Resistant to tobramycin $(10 \mu \mathrm{g})$. Principal fatty acids are $16: 0,18: 1 \omega 7 c$ and $16: 1 \omega 7 c$. The predominant respiratory lipoquinone is ubiquinone with nine isoprene units (Q-9). The DNA $\mathrm{G}+\mathrm{C}$ content is between 62.7 and $66.2 \mathrm{~mol} \%$.
The type strain, $\mathrm{SP} 4^{\mathrm{T}}$, grows in a medium containing only $5 \%(\mathrm{w} / \mathrm{v}) \mathrm{NaCl}$. It hydrolyses tyrosine and Tween 80 but not gelatin. It does not survive for $10 \mathrm{~min}$ at $80{ }^{\circ} \mathrm{C}$. Salicin, ethanol and serine serve as sole carbon and energy sources. It does not utilize arabinose, cellobiose, fructose, lactose, starch, trehalose, lactate, adonitol, glycerol, inositol, mannitol or histidine. The principal fatty acids of the type strain are: $16: 0(33.9 \%) ; 16: 1 \omega 7 c(18.72 \%) ; 18: 1 \omega 7 c(16.08 \%)$; 19:0 cyclo $\omega 8 c(14.46 \%)$ and $12: 03-\mathrm{OH}(6.22 \%)$. The predominant respiratory lipoquinone is ubiquinone with nine isoprene units (Q-9). The DNA G+C content of the type strain is $66.2 \mathrm{~mol} \%$ ( $T_{\mathrm{m}}$ method).

The type strain, SP4 $4^{\mathrm{T}}\left(=\mathrm{CECT} 7282^{\mathrm{T}}=\mathrm{LMG} 24145^{\mathrm{T}}\right.$ ), was isolated from a saline soil.

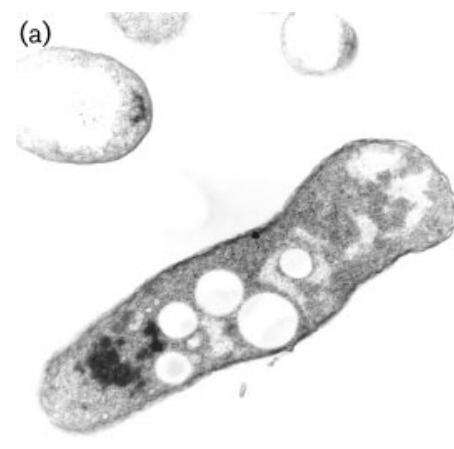

(b)

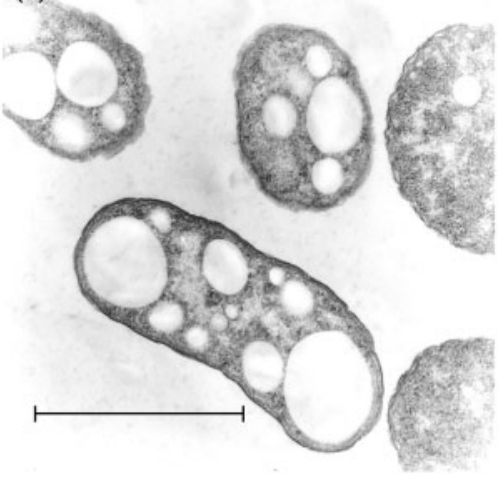

(c)
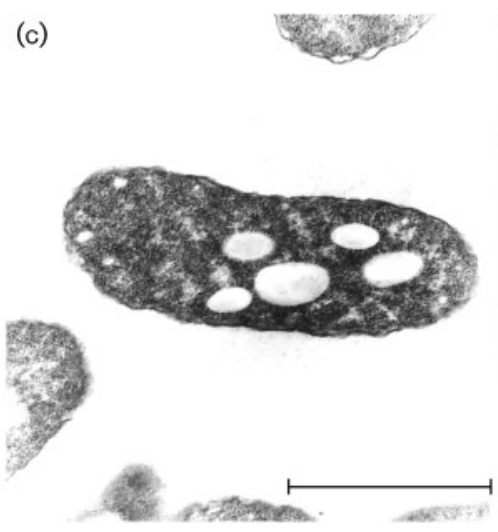

Fig. 2. Transmission electron micrographs of cells of strains $15 \mathrm{CR}(\mathrm{a}), \mathrm{R} 53$ (b) and $\mathrm{SP} 4^{\top}$ (c) stained with ruthenium red. Bars, $1 \mu \mathrm{m}$. 


\section{Acknowledgements}

This research was supported by grants from the Dirección General de Investigación Científica y Técnica (BOS2003-0498; CGL2005-05947) and from the Plan Andaluz de Investigación, Spain. Thanks go to $\mathrm{M}^{\mathrm{a}}$ José Martínez-Cánovas, who isolated the strains and to Concepción Hernandez and David Porcel from the Centro de Instrumentación Científica (Universidad de Granada) for their expertise in microscope studies. We also thank our colleague Dr J. Trout for revising our English text and for his help with the species name.

\section{References}

Arias, S., Del Moral, A., Ferrer, M. R., Quesada, E. \& Béjar, V. (2003). Mauran, an exopolysaccharide produced by the halophilic bacterium Halomonas maura, with a novel composition and interesting properties for biotechnology. Extremophiles 7, 319-326.

Bouchotroch, S., Quesada, E., Del Moral, A., Llamas, I. \& Béjar, V. (2001). Halomonas maura sp. nov., a novel moderately halophilic, exopolysaccharide-producing bacterium. Int J Syst Evol Microbiol 51, 1625-1632.

Dobson, S. J. \& Franzmann, P. D. (1996). Unification of the genera Deleya (Bauman et al. 1993), Halomonas (Vreeland et al. 1980), and Halovibrio (Fendrich 1988) and the species Paracoccus halodenitrificans (Robinson and Gibbons 1952) into a single genus, Halomonas, and placement of the genus Zymobacter in the family Halomonadaceae. Int J Syst Bacteriol 46, 550-558.

Euzéby, J. P. (2007). List of Prokaryotic Names with Standing in Nomenclature. http://www.bacterio.cict.fr/

Franzmann, P. D. \& Tindall, B. J. (1990). A chemotaxonomic study of members of the family Halomonadaceae. Syst Appl Microbiol 13, 142-147.

Franzmann, P. D., Wehmeyer, U. \& Stackebrandt, E. (1988). Halomonadaceae fam. nov., a new family of the class Proteobacteria to accommodate the genera Halomonas and Deleya. Syst Appl Microbiol 11, 16-19.

Garrity, G. M., Bell, J. A. \& Liburn, T. (2005). Family IV. Halomomadaceae Franzmann, Wehmeyer and Stackebrandt 1989, $205^{\mathrm{VP}}$ emend. Dobson and Franzmann 1996, 558. In Bergey's Manual of Systematic Bacteriology, 2nd edn, vol. 2. Edited by D. J. Brenner, N. R. Krieg, J. T. Staley \& G. M. Garrity. New York: Springer.

Kumar, S., Tamura, K. \& Nei, M. (2004). MEGA3: integrated software for Molecular Evolutionary Genetics Analysis and sequence alignment. Brief Bioinform 5, 150-163.

Lind, E. \& Ursing, J. (1986). Clinical strains of Enterobacter agglomerans (synonyms: Erwinia herbicola, Erwinia milletiae) identified by DNA-DNA hybridization. Acta Pathol Microbiol Immunol Scand $[B]$ 94, 205-213.

Marmur, J. \& Doty, P. (1962). Determination of the base composition of deoxyribonucleic acid from its thermal denaturation temperature. J Mol Biol 5, 109-118.

Martínez-Cánovas, M. J., Béjar, V., Martínez-Checa, F. \& Quesada, E. (2004a). Halomonas anticariensis sp. nov., from Fuente de Piedra, a saline-wetland wildfowl reserve in Málaga, southern Spain. Int J Syst Evol Microbiol 54, 1329-1332.

Martínez-Cánovas, M. J., Quesada, E., Llamas, I. \& Bejar, V. (2004b). Halomonas ventosae sp. nov., a moderately halophilic, denitrifying, exopolysaccharide-producing bacterium. Int J Syst Evol Microbiol 54, 733-737.

Martínez-Checa, F., Béjar, V., Martinez-Cánovas, M. J., Llamas, I. \& Quesada, E. (2005). Halomonas almeriensis sp. nov., a moderately halophilic, exopolysaccharide-producing bacterium from Cabo de Gata, Almería, south-east Spain. Int J Syst Evol Microbiol 55, 2007-2011.

Mata, J. A., Martínez-Cánovas, M. J., Quesada, E. \& Béjar, V. (2002). A detailed phenotypic characterization of the type strains of Halomonas species. Syst Appl Microbiol 25, 360-375.

Moraine, R. A. \& Rogovin, P. (1966). Kinetics of polysaccharide B-1459 fermentation. Biotechnol Bioeng 8, 511-524.

Owen, R. J. \& Hill, L. R. (1979). The estimation of base compositions, base pairing and genome sizes of bacterial deoxyribonucleic acids. In Identification Methods for Microbiologists (Society for Applied Bacteriology Technical Series no. 14), 2nd edn, pp. 277-296. Edited by F. A. Skinner \& D. W. Lovelock. London: Academic Press.

Owen, R. J. \& Pitcher, D. (1985). Current methods for estimating DNA composition and levels of DNA-DNA hybridization. In Chemical Methods in Bacterial Systematics, pp. 67-93. Edited by M. Goodfellow \& D. E. Minnikin. London: Academic Press.

Quesada, E., Ventosa, A., Rodríguez-Valera, F., Megías, L. \& RamosCormenzana, A. (1983). Numerical taxonomy of moderately halophilic Gram-negative bacteria from hypersaline soils. J Gen Microbiol 129, 2649-2657.

Quesada, E., Valderrama, M. J., Béjar, V., Ventosa, A., Gutiérrez, M. C., Ruíz-Berraquero, F. \& Ramos-Cormenzana, A. (1990). Volcaniella eurihalina gen. nov., sp. nov., a moderately halophilic nonmotile Gram-negative rod. Int J Syst Bacteriol 40, 261-267.

Quesada, E., Béjar, V., Del Moral, A., Ferrer, M. R., Calvo, C., Llamas, I., Martínez-Checa, F., Arias, S., Ruiz-Garcia, C. \& other authors (2004). Moderately halophilic, exopolysaccharide-producing bacteria. In Halophilic Microorganisms, pp. 297-314. Edited by A. Ventosa. Heidelberg: Springer-Verlag.

Rodríguez-Valera, F., Ruiz-Berraquero, F. \& Ramos-Cormenzana, A. (1981). Characteristics of the heterotropic bacterial populations in hypersaline environments of different salt concentrations. Microb Ecol 7, 235-243.

Romanenko, L. A., Schumann, P., Rohde, M., Mikhailov, V. V. \& Stackebrandt, E. (2002). Halomonas halocynthiae sp. nov., isolated from the marine ascidian Halocynthia aurantium. Int J Syst Evol Microbiol 52, 1767-1772.

Romano, I., Giordano, A., Lama, L., Nicolaus, B. \& Gambacorta, A. (2005). Halomonas campaniensis sp. nov., a haloalkaliphilic bacterium isolated from a mineral pool of Campania Region, Italy. Syst Appl Microbiol 28, 610-618.

Sneath, P. H. A. \& Sokal, R. R. (1973). Numerical taxonomy. The Principles and Practice of Numerical Classification. San Francisco: Freeman, Williams \& Wilkins Co.

Sokal, R. R. \& Michener, C. D. (1958). A statistical method for evaluating systematic relationships. Sci Bull 38, 1409-1438.

Stanier, R. Y., Palleroni, N. J. \& Duodoroff, M. (1966). The aerobic pseudomonads: a taxonomic study. J Gen Microbiol 43, 159-271.

Thompson, J. D., Gibson, T. J., Plewniak, K., Jeanmougin, F. \& Higgins, D. G. (1997). The CLUSTAL_X windows interface: flexible strategies for multiple sequence alignments aided by quality analysis tools. Nucleic Acids Res 25, 4876-4882.

Ventosa, A., Quesada, E., Rodriguez-Valera, F., Ruiz-Berraquero, F. \& Ramos-Cormenzana, A. (1982). Numerical taxonomy of moderately halophilic Gram-negative rods. J Gen Microbiol 128, 1959-1968.

Ventosa, A., Nieto, J. J. \& Oren, A. (1998). Biology of moderately halophilic aerobic bacteria. Microbiol Mol Biol Rev 62, 504-544.

Vreeland, R. H. (2005). Genus Halomonas. In Bergey's Manual of Systematic Bacteriology, 2nd edn, vol. 2. The Proteobacteria, pp. 316319. Edited by G. Garrity, D. J. Brenner, N. R. Krieg \& J. T. Staley. New York: Springer. 
Wang, Y. N., Cai, H., Yu, S. L., Wang, Z., Liu, J. \& Wu, X. L. (2007). Halomonas gudaonensis sp. nov., isolated from a saline soil contaminated by crude oil. Int J Syst Evol Microbiol 57, 911-915.

Yoon, J. H., Lee, K. C., Kho, Y. H., Kang, K. H., Kim, C. J. \& Park, Y. H.

(2002). Halomonas alimentaria sp. nov., isolated from jeotgal, a traditional Korean fermented seafood. Int J Syst Evol Microbiol 52, 123-130.

Ziemke, F., Manfred, G. H., Lalucat, J. \& Roselló-Mora, R. (1998). Reclassification of Shewanella putrefaciens Owen's genomic group II as Shewanella baltica sp. nov. Int J Syst Bacteriol 48, 179-186. 